\title{
Effect Of Good Corporate Governance On Company Profitability RE \& Property Sector In Indonesia
}

\author{
Ahmad Azmy, Dea Restiya Anggreini, and Mohammad Hamim \\ School of Management \& Leadership \\ Tanri Abeng University \\ ahmad.azmy@tau.ac.id,dea.restiya@student.tau.ac.id,hans.mohamad@tau.ac.id
}

\begin{abstract}
This study aims to examine the effect of Good Corporate Governance (GCG) on company profitability. The dependent variable are Return On Assets (ROA) and Return On Equity (ROE). The independent variable are Good Corporate Governance (GCG) represented by the Board of Commissioners, the Board of Directors, and the Audit Committee. This study uses secondary data from audited financial statements of Real Estate and Property companies in 2013-2017. The analytical tool used in this study uses panel data regression. Based on the results of the study it is known that the Board of Directors and Audit Committee variables have a significant positive effect on ROA and ROE. The Board of Commissioners variable has no influence and negative relationship to ROA and ROE.
\end{abstract}

Keywords: Profitability, Good Corporate Governance.

\section{INTROCUDTION}

The term corporate governance began to emerge in Indonesia in 1998 when Indonesia experienced a prolonged economic crisis that was assessed because it did not manage the company responsibly, resulting in many being depressed because they could not survive (Marsella, 2013). The word governance comes from French, namely "gubernance" which means control, in its development the word governance is widely used in the context of corporate activities into corporate governance which if translated in Indonesian is corporate governance or governance (Sutojo and Aldridge, 2008). At present corporate governance has become a necessity and demands for business people and the government also provide a very strong impetus to the implementation of corporate governance by issuing regulations that regulate how the implementation of good corporate governance in the company.

According to (Santoso, 2009) the Real Estate and Property industry is one sector that signals a fall or the development of a country's economy. Many companies engaged in the Real Estate and Property sector indicate the growing economy in the country. The following are data regarding the growth of ROA and ROE from several Real Estate and Property companies in Indonesia, such as PT. Alam Sutera Realty, Tbk (ASRI), PT. Bumi Serpong Damai, Tbk (BSDE), PT. Jaya Real Property, Tbk (JRPT), PT. PT. Metropolitan Kentjana, Tbk (MKPI), and PT. Metropolitan Land, Tbk (MTLA): The current conditions related to profitability in the real estate and property business sector that are proxied with Return on Assets (ROA) and Return on Equirt (ROE) are as follows: 


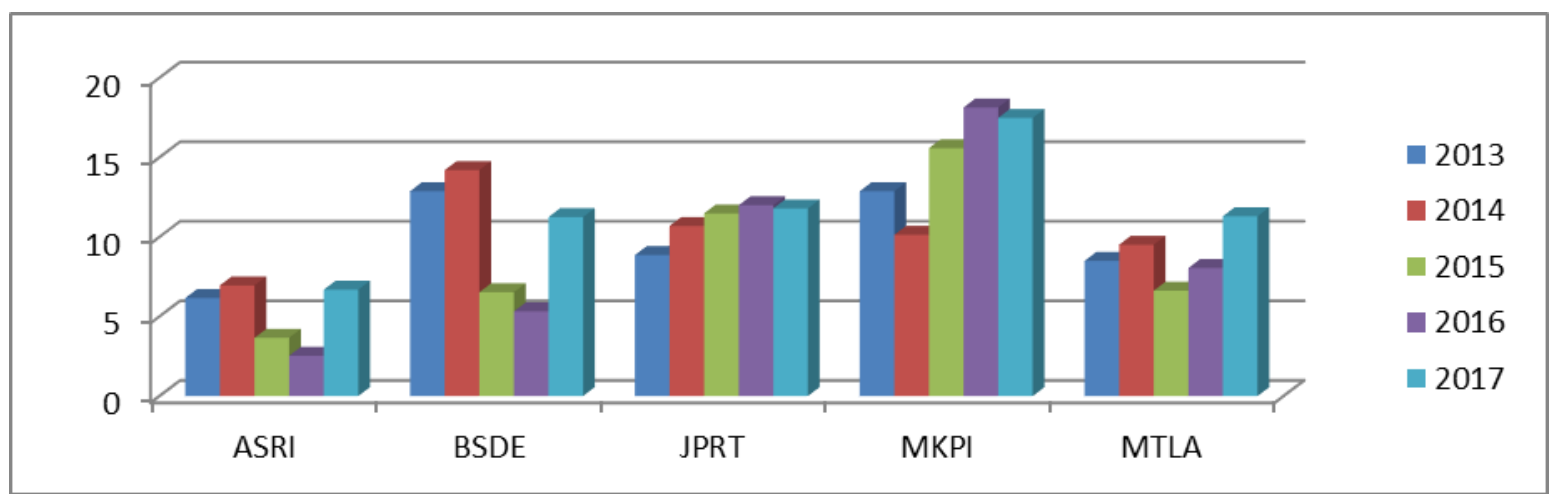

Figure 1. Graph of Return on Assets of Company Real Estate and Property Sector 2013 - 2017 Source : Data processed

Based on the graph above, it can be seen that ROA has increased and decreased every year. Changes in ROA levels can be caused by sales growth. Every year the community's needs for housing will increase, so that automatic demand will also increase. This can be seen from the graph above, some companies experienced an increase in ROA in 2017, although some also experienced a decline but not too significant.

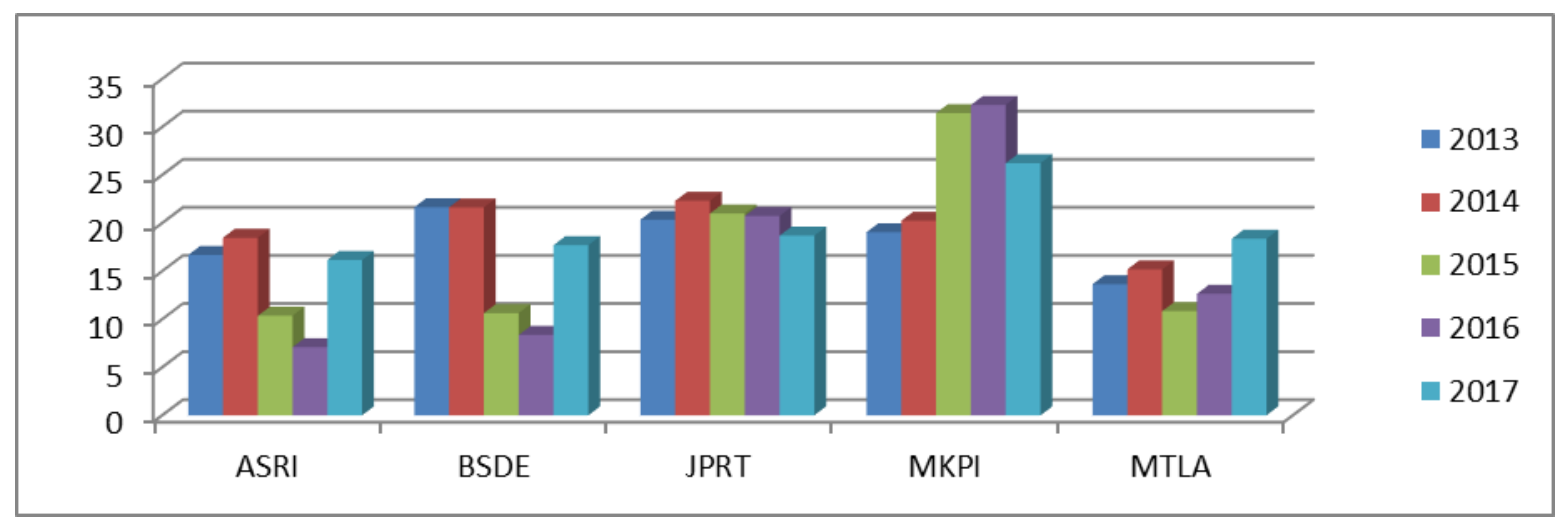

Figure 2. Graph of Return on Equity of Company Real Estate and Property Sector 2013 - 2017 Source: Data processed

The ROE growth chart also changes every year. ROE measurement is one of the most important ones used in the Real Estate and Property business because investors will usually look at financial performance and assess the level of profitability of the company before investing. If the ROE is good, the other profitability ratios will also be good. According to KNKG (2006) there are five basic principles of corporate governance that must be implemented by companies so that corporate governance practices can be implemented well, namely Transparency is openness in implementing decision-making processes and openness in expressing clear information regarding financial conditions, corporate management, operational performance and ownership. Accountability is a principle that regulates the clarity of functions, implementation and accountability of the organization so that company management is carried out effectively. Responsibility, namely conformity in the management of the company to the applicable laws and regulations and sound corporate principles. Independency is a condition where the company is managed professionally without conflict of interest and influence from any 
party that is not in accordance with applicable regulations and sound corporate principles. Fairness, namely justice and equality in fulfilling the rights of stakeholders that arise based on agreements and applicable laws.

The purpose of establishing a company is to generate maximum profit for shareholders. Through the profits obtained, the company will be able to provide dividends to shareholders, increase company growth, and maintain the sustainability of the company. However, to achieve these objectives, there will always be obstacles and problems faced by the company both external and internal problems. Cases that have befallen Enron and PT. Bank Lippo, Tbk is an example of the implementation of good governance in the company. Both of these cases have similarities, namely fraud committed by the internal company that seeks profit for itself which causes losses to the company. Cases that have occurred in the implementation of corporate governance in a company are expected to reduce and prevent various risks that might be carried out by the management of the company that could harm the company. The relationship between corporate governance and profitability is through better corporate performance that will reflect a good impression on investors, so the company will increase its ability to obtain high profits. In this study profit will be measured by profitability ratios proxied by Return On Assets (ROA) and Return On Equity (ROE).

Research on the effect of applying good corporate governance on profitability is the impact of Good Corporate Governance on profitability and stock performance in banking companies (David, 2011). The results of the study found that Good Corporate Governance has a significant positive impact on profitability as measured by Return On Assets (ROA), Return On Equity (ROE), Net Interest Margin (NIM), and Price to Earning Ratio (PER). A similar study was also carried out by (Tumewu and Alexander, 2014) on banking companies listed on the Stock Exchange mentioning that corporate governance had a significant positive effect on the profitability of banking companies. Profitability is measured by Return On Equity (ROE). The results of this study concluded that the better the application of corporate governance will increase the company's ability to generate profits. But this result is not in line with other studies which state that corporate governance has a significant effect on Return On Assets (ROA) but not on Return On Equity (ROE) (Putra and Nuzula, 2017).

Based on the background described and the differences in the results of previous studies, the researchers are interested in conducting research again on the effect of the application of good corporate governance to profitability. In this study, good corporate governance is proxied with the Board of Commissioners, the Board of Directors, and the Audit Committee. Variable profitability is measured by Return On Assets (ROA) and Return On Equity (ROE). The research sample is a Real Estate and Property Sector Company listed on the Indonesia Stock Exchange (IDX) in the period 2013-2017. Based on the description, this study entitled "The Effect of Good Corporate Governance on the Profitability of Real Estate and Property Sector Companies in Indonesia."

\section{THEORETICAL REVIEW}

Agency Theory. The theory related to corporate governance is agency theory. (Jensen et al., 1976) explained that "agency relationships are contracts where the principal (shareholder) orders the agent (management) to do a service on behalf of the principal and 
authorizes the agent to make the best decision for the principal". Agency theory emphasizes the establishment of efficient contractual arrangements in the relationship between the principal and the agent. An efficient contract is a contract that contains a clear picture of the principal and agent's rights and obligations, so as to minimize agency conflict and minimize agency costs. Principal delegates a decision-making responsibility to the manager (agent) in accordance with the employment contract. The duties, authority, rights and responsibilities of agents and principals are regulated in a mutually agreed work contract. The relationship between the principal and agent is fundamental to the practice of implementing corporate governance. Corporate governance is expected to function as a tool to provide investors and shareholders with confidence that they will receive returns on invested funds (Noorizkie, 2013).

Good Corporate Governance. According to the Forum for Corporate Governance in Indonesia (FCGI, 2001), "corporate governance is a set of rules that establish relationships between shareholders, administrators, creditors, governments, employees and other internal and external stakeholders in relation to their rights and obligations, or in other words a system that directs and controls the company ". The Organization for Economic Co Operation and Development (OECD) cited by (Aldridge et al., 2008), the definition of corporate governance is a system used to direct and manage company activities. Corporate governance regulates the distribution of duties, rights, and obligations of the company management, board of directors, shareholders, and other parties who have an interest in the company. Corporate governance also requires the structure of the device to achieve goals and oversee performance. The existence of a good corporate governance system is expected to have a good effect on management to achieve goals that are in the interests of the company and shareholders and must facilitate effective monitoring, thereby encouraging companies to use resources more efficiently (Surya and Yustiavandana, 2006) . Based on some of the above meanings, it can be concluded that corporate governance is a system that regulates, manages and supervises the business control process that runs sustainably to increase company value, as well as a form of attention to stakeholders, employees, creditors, and the surrounding community.

Board of Commissioners. (Veno, 2015) stated that, the Board of Commissioners is the representative of shareholders in a company incorporated as a Limited Company. This board functions to oversee the management of company data carried out by management (directors). Thus, the board of commissioners who actively carry out their functions can prevent too much control in the hands of management (directors). According to the National Committee on Governance Policy (KNKG) defines the Board of Commissioners as the highest internal control mechanism that is collectively responsible for supervising and giving input to the directors and ensuring that companies carry out good corporate governance (KNKG, 2006).

According to the Republic of Indonesia Law Number 40 of 2007 concerning Limited Liability Companies in (Hutapea and Prasetiono, 2013), the Board of Commissioners is a corporate organ that is tasked with conducting general and special supervision in accordance with the articles of association and is tasked with providing advice to directors. According to the Forum for Corporate Governance Indonesia (FCGI, 2001) defines the Board of Commissioners as the core of corporate governance that is tasked with ensuring 
the implementation of the company's strategy, overseeing management in managing the company, and requiring accountability. In general, the board of commissioners is an important organ that acts as a representative of the company owner (stakeholder) who is responsible for overseeing the management activities of the company in accordance with what the stakeholders expect.

Based on several definitions according to experts, it can be concluded that the Board of Commissioners is a corporate organ that is responsible for overseeing and controlling management in managing the company, and ensuring that the company has implemented good governance. The board of commissioners must be able to carry out the oversight function properly, because if the task is negligent it will have an impact on the decline in company performance.

Board of Directors. The Board of Directors is a party in a company as the executor of operations and management of the company. Appointment and dismissal of the board of directors, determination of the amount of income, and the distribution of duties and authority of each member of the board carried out at the General Meeting of Shareholders (GMS). The main tasks given to directors in a company will determine the policies that will be taken or the company's strategy in the short and long term. The Board of Directors must supervise and ensure that the company has fully implemented all the provisions stipulated in the articles of association and applicable laws and regulations.

The Board of Directors is the organ of the company that has the authority and full responsibility for the company's management for the company's interests, in accordance with the company's goals and objectives and represents the company both inside and outside the court in accordance with statutes (UUD No. 40 of 2007 concerning Limited Liability Companies). Based on the definitions from several sources, the Board of Directors is the party that has the authority to manage and manage the company, as well as determine the company's policies and strategies in accordance with the applicable rules and regulations.

Audit Committee. (Veno, 2015) explained that the role of the audit committee was regulated in Bapepam No. Kep-29 / M / 2004 where a work unit is formed by the board of commissioners in order to help carry out their duties and functions. The Audit Committee is a small committee of directors who are independent and outside the director. The Audit Committee has broad responsibility for the company's external reports, monitors risks, and controls the process and performs internal and external audit functions. The audit committee is not involved in preparing financial reports directly. The audit committee acts as an independent management examiner and as a lawyer for users outside the financial statements in ensuring that financial statements are accurately presented that describe the company's economic activities. The audit committee has the task of assisting the board of commissioners by providing professional and independent opinions to improve the quality of work and reduce deviations in management of the company (Surya and Yustiavandana, 2006).

Profitability. According to (Munawir, 2014) the definition of profitability is to show the company's ability to generate profits for a certain period. The profit of a company is 
measured by the success of the company and the ability to use its assets productively, thus the profitability of a company can be known by comparing the profits earned in a period with the total assets or total capital of the company. (Sartono, 2010) argues that profitability is the ability of companies to earn profits in relation to sales, total assets and own capital. Profit is one measure of the success of company performance.

The theory of profitability as one of the references in measuring the amount of profit becomes so important to know whether the company has run its business efficiently. The efficiency of a new business can be known after comparing the profits obtained with the assets or capital that produces the profit. Based on the opinions of experts, profitability is a measure of a company's ability to utilize its assets and capital. Profit shows how well the company's performance will have an impact on investment decisions, because profit is one of the main attractions for investors to invest in a company. If profit is high, the return on investment will also be high and in accordance with what is expected by investors and shareholders. The profitability ratio used in this study is as follows:

Return on Assets (ROA). According to (Sawir, 2005), Return On Assets (ROA) is a ratio used to measure the ability of a company's management to obtain profits (profits) as a whole. This ratio also shows the effectiveness of management in using assets to generate income for the company. Return On Assets (ROA) can be calculated using the following formula:

$$
\mathrm{ROA}=\frac{\text { Net Income }}{\text { Total Asset }} \times 100 \%
$$

Return on Equity (ROE). Return On Equity (ROE) is one of the profitability ratios to measure the level of profits obtained by the company. This indicator shows the company's ability to generate post-tax profits by using the company's own capital. This ratio is important for shareholders to know the effectiveness and efficiency of self-capital processing carried out by the management of the company. The higher the ratio means the more efficient the use of own capital by the company. This ratio is also a measure of the success of a company that is major and has an important influence on the survival of a company

Return on Equity (ROE) is more of a concern to shareholders because it relates to the share capital invested in management. For management as an internal company, Return On Equity has an important meaning to assess company performance in meeting shareholder expectations (Helfert, 2000). According to Brigham and Houston (2015) explained that shareholders make investments to get returns on their money. ROE can be calculated using the following formula:

$$
\text { ROE }=\frac{\text { Net Income }}{\text { Total Equity }} \times 100 \%
$$

The above theory explains that good corporate governance has good implications for company profitability. (Sanda et al., 2010) explained that managerial ownership, board size, and independent commissioners had a non-significant effect on ROA, ROE, and Tobin's Q. CEO expatriates had a significant effect on ROA, while leverage and firm size 
had a negative and significant effect on ROE. and (Tobin's Q. Tjondro and Wilopo, 2011) revealed that Good Corporate Governance (GCG) has a significant positive impact on Return On Assets (ROA), Return On Equity (ROE), Net Interest Margin (NIM), and Price to Earning Ratio ( PER), while for stock returns, Good Corporate Governance does not have a significant impact. (Hardikasari et al., 2011) concludes that the size of the board of directors has a significant negative effect on financial performance, the size of the board of commissioners has a significant positive effect on company performance and the size of the company has a significant positive effect on financial performance.

(Kajananthan, 2012) explains that corporate governance practices have a $34 \%$ impact on capital structure and among CG board committee variables have a significant influence on the company's capital structure. (Hutapea and Prasetiono, 2013) explained that the board of commissioners had a positive and not significant effect on financial performance, while the board of directors and company size had a positive and significant effect on financial performance. (Chukwudike, 2012) shows that the relationship between the corporate governance mechanism towards ROE and $75.3 \%$ of the total variation observed in the dependent variable (ROE) is explained by the independent variable (Corporate Governance). Specifically, the results show evidence of a significant negative relationship between the board of commissioners and the independent director of ROE. This means that the bigger the board of commissioners, the less profitability of the company. The results also showed a significant positive relationship between the audit committee and ROE. However, this study cannot show evidence of a significant relationship between board independence and regulatory and ROE mechanisms. (Fidanoski et al., 2013) explained that the board of commissioners had a significant positive relationship to ROA and was not significant to ROE.

(Nurcahyani et al., 2011) showed that corporate governance (GCG) had an effect on profitability both proxied by ROA and ROE. (Tumewu and Alexander, 2014) explained that GCG had a significant positive effect on the profitability of banking companies. This means that the better the implementation of GCG will increase the company's ability to generate profits which in this case is measured by ROE. (Wicaksono and Rahardja, 2014) provide an understanding of corporate governance (GCG) that has no significant effect on company profitability. (Nwonyuku, 2016) revealed that the board of commissioners has a positive relationship with ROE and net assets per share. Board composition has a negative relationship to ROE, but has a positive relationship to net assets per share. Board skills and competencies have a negative relationship to ROE and net assets per share. While gender diversity shows a positive relationship to ROE and net assets per share.

Based on the explanation of the theory and previous research above, it can be concluded that the management of the company is assumed to affect the size of the profitability obtained by the company. Good corporate governance will be able to increase profitability both for increasing equity and company assets. Therefore, the framework used in this study is as follows: 


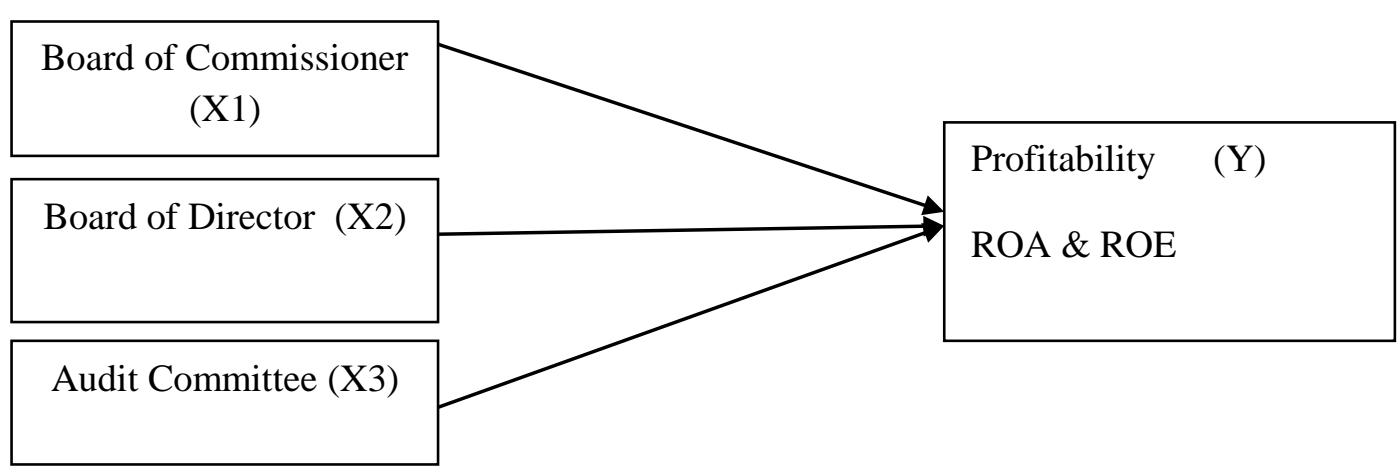

Figure 3. Relationship among Thought Variables

The picture above explains that the independent variable is assumed to have a positive effect on the dependent variable. This assumption is supported by previous research that has been done before. Previous research conducted by (Nwonyuku, 2016) stated that there was a positive relationship between board of commissioners and profitability. The more the board of commissioners, the better the function of supervision of management in the company. Furthermore, the results of other studies state that the board of directors has a positive effect on profitability, this is because the more directors will improve the performance of a company (Rimardhani et al., 2016). (Anjani, 2017) proves that audit committees have a positive effect on profitability.

\section{METHODOLOGY}

Data collection. This study aims to determine the relationship and influence between two or more variables. The data used in this research is secondary data. The data collection method used in this study is the documentation method. Documentation method is a method of collecting data by studying notes or documents (Sukandar et al., 2014). The secondary data in this study are the annual financial statements of Real Estate and Property companies which are published annually in the period 2013 to 2017. Data is obtained from the company's annual financial statements taken from the Indonesia Stock Exchange (IDX) website, www.idx. co.id.

Population and Samples. The population in this study were Real Estate and Property companies listed on the IDX for the period 2013-2017. In this study the sample was taken using a purposive sampling technique. The sample chosen must meet several predetermined criteria, namely the Real Estate and Property Company listed on the IDX that publishes the audited financial statements in full during the period 2013-2017, and provides complete data on information on the board of commissioners, board of directors, and audit committee. This study uses annual data from 2013 - 2017 so that it has complete information related to information on both independent and dependent variables. Based on these criteria, 28 Real Estate and Property companies were obtained as samples in this study. 
Research methods. The analytical method used in this research is panel data regression analysis. (Ajija et al., 2011) explained that panel data is a combination of time series data (sequential time) and cross section. There are three methods that can be used as follows 1. Pooled least square (PLS) is a method that estimates panel data with the OLS method.

2. Fixed effect (FE) is a method that adds a dummy model to the panel data.

3. Random effect (RE) is a method that calculates errors from panel data by the least square method. This study will use the Pooled least square (PLS) method to interpret the data according to the regression equation as follows:

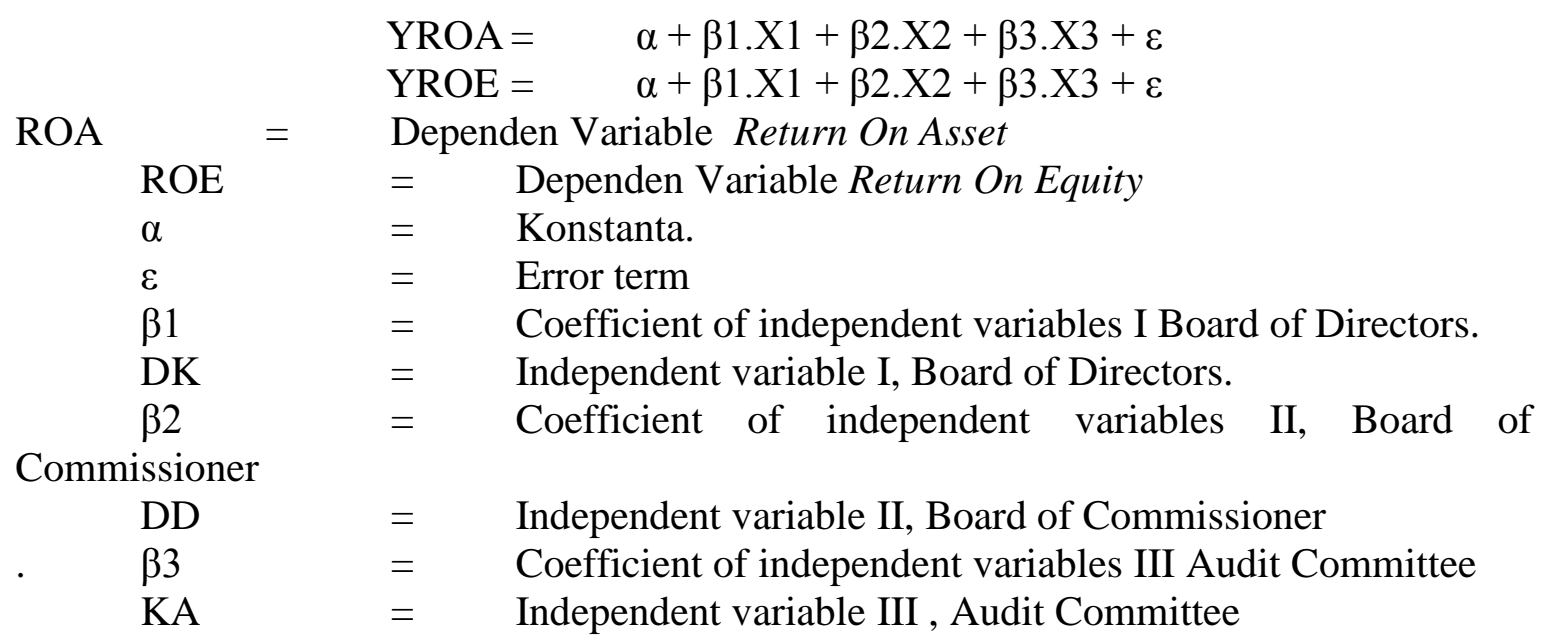

Research Hypothesis. Based on the theoretical foundation and previous research described earlier, the hypotheses of this study are as follows:

Effect of the Board of Directors on Profitability. According to Law Number 40 of 2007 concerning Limited Liability Companies, the Board of Directors is a company organ that has the authority and full responsibility for the company's management for the company's interests, in accordance with the company's goals and objectives and representing the company both inside and outside the court in accordance with the provisions of the Articles of Association. Research conducted by (Rimardhani et al., 2016) and (Septiana et al., 2016) prove that the board of directors influences the profitability of the company.

H1: The Board of Directors has a positive influence on profitability

Effect of the Board of Commissioners on Profitability. The National Governance Policy Committee (KNKG, 2006) explains that the board of commissioners is the highest internal control mechanism that is responsible for supervising and giving input to the directors and ensuring that the company implements good corporate governance. The results of the study prove that the board of commissioners has a positive relationship to financial performance (Hardikasari et al., 2011). The results of these studies are also supported by the results of research conducted by (Hutapea and Prasetiono, 2013) and (Sunarwan, 2015) which state that the size of the board of commissioners has a positive effect on financial performance.

H2: The board of commissioners has a positive influence on profitability. 
Effect of the Audit Committee on Profitability. The audit committee stands as a liaison between shareholders and the board of commissioners with the management in order to overcome control problems or the possibility of agency problems (Noorizkie, 2013). research conducted by (Anjani, 2017) proves that audit committees have a positive influence on profitability. So it can be concluded that the audit committee has a positive influence on profitability to oversee corporate governance.

H3: The Audit Committee has a positive influence on Profitability

\section{The Results of Statistical Tests}

Model Testing. Panel data regression research model to test the compatibility of common effects, fixed effects, and random effects. (Ajja et al., 2011) explained that testing the suitability of the model does use some of the effects that exist in panel data regression using the Chow Test (compatibility using common effect / fixed effect) and Hausman Test (compatibility using fixed effect / random effect). Below are the results of testing the panel data regression model as follows.

Table 1. Chow Test Results

\begin{tabular}{cccc}
\hline Chow Test & Statistic & d.f. & Chi Square Test Prob. \\
\hline ROA & 0.0000 & 4.0000 & 1.0000 \\
ROE & 0.0000 & 4.0000 & 1.0000 \\
\hline
\end{tabular}

Sources : Data processed

The Chow Test results in the table above show two dependent variables Return on Assets (ROA) and Return Equity (ROE) that the prob value in the Chi-Square Test is 1.00>0.05. This shows that the common effect is more suitable than the fixed effect on both dependent variables Return on Assets (ROA) and Return on Equity (ROE). Below, the Hausmann Test results are as follows:

Table 2. Hausmann Test Result

\begin{tabular}{cccc}
\hline Hausmann Test & Chi-Sq. Statistic & Chi-Sq. d.f. & $\begin{array}{c}\text { Cross Section Random } \\
\text { Prob. }\end{array}$ \\
\hline ROA & 0.0000 & 3.0000 & 1.0000 \\
ROE & 0.0000 & 3.0000 & 1.0000 \\
\hline
\end{tabular}

Sources : Data processed

Hausmann Test Results using two dependent variables Return on Assets (ROA) and Return on Equity (ROE) in table II that the value of prob cross section random 1.00>0.05. This indicates that fixed effects are more suitable than random effects. However, the Chow Test results for the two dependent variables do not show fixed effect compatibility in panel data regression modeling. Therefore, panel data regression modeling uses common effect or pooled least square (PLS).

Panel Data Regression Model. Based on the results of the Chow test and the Hausmann Test that fixed effects and random effects are not suitable for use as a panel data interpretation model. Therefore, this panel data interpretation model that is suitable uses a 
common effect. The results of the research mode are conducted separately between the dependent variables Return on Assets (ROA) and Return on Equity (ROE). The results of the study show similarities for the two dependent variables. Below, the results of the panel data regression research model using the common effect are as follows:

Table 3. Results of Panel Data Regression Variable Return on Assets (ROA) and Return on Equity (ROE)

\begin{tabular}{lr}
\hline R-Square & 0.866141 \\
Adjusted R-Square & 0.86566 \\
Prob (F-Statistic) & 0.0000 \\
\hline
\end{tabular}

Sources: Data Processed

Based on the results above, there is a similarity of results between the dependent variables Return on Assets (ROA) and Return on Equity (ROE). The coefficient of determination using the common effect (CE) model between the variables Return on Assets (ROA) and Return on Equity (ROE) both have the same percentage. The Adjusted R-Square amount is $87 \%$ where the three variables of the Board of Directors (BoD), Board of Commissioners (BoC), and Audit Committee (AC) are able to influence the dependent variable Return on Assets (ROA) and Return on Equity (ROE). Then the Prob (F-Statistic) of $0.00<0.05$ where simultaneously the three independent variables of the Board of Directors, the Board of Commissioners, and the Audit Committee have a significant influence on the dependent variable Return on Assets (ROA) and Return on Equity (ROE). Below this the results of the Partial T-Test for the two dependent variables Return on Assets (ROA) and Return on Equity (ROE) are as follows:

Table 4. Test Results for Panel Data Regression Return on Assets (ROA) and Return on Equity (ROE)

\begin{tabular}{crrrc}
\hline Variable & Coefficient & Std. Error & t-Statistic & Prob. \\
\hline BoD & 0.538493 & 0.094945 & 5.67163 & 0.0000 \\
BoC & -0.28866 & 0.165948 & -1.73944 & 0.0825 \\
AC & 1.527476 & 0.026209 & 58.28152 & 0.0000 \\
\hline
\end{tabular}

Sources : Data Processed

The results of the table above show that the Board of Directors (BoD) and Audit Committee (AC) have a partial influence on Return on Assets (ROA) and Return on Equity (ROE). This is due to the Prob value of each independent variable $0.0000<0.05$. The Board of Commissioners (BoC) variable does not have a partial effect on Return on Assets (ROA) and Return on Equity (ROE). This is because the value of the Prob is 0.08> 0.05 so that hypothetically rejects and has no influence on the dependent variable both Return on Assets (ROA) and Return on Equity (ROE) 


\section{DISCUSSION}

Below is a panel data regression model using the common effect approach, both Return on Assets (ROA) and Return on Equity (ROE) as follows:

$$
\begin{aligned}
& \mathrm{ROA}=0.538592045213 * \mathrm{BoD}-0.288739847954 * \mathrm{BoC}+1.52750664866 * \mathrm{AC} \\
& \mathrm{ROE}=0.538493359522 * \mathrm{BoD}-0.288657249023 * \mathrm{BoC}+1.52747566452 * \mathrm{AC}
\end{aligned}
$$

Based on the panel data regression model with the dependent variable Return on Assets (ROA) and Return on Equity (ROE) have the same results. According to the results of the $T$ test that the Board of Directors (BoD) has a significant influence on ROA \& ROE. The performance of the Board of Directors (BoD) is able to increase profitability by 0.538 (53.8\%) both for Return on Assets (ROA) and Return on Equity (ROE). Because the board of directors coefficient value is positive, then there is an influence between the board of directors on ROA. This is because the board of directors will manage the company well, and take policies that can provide benefits and increase company assets (Hutapea and Prasetiono, 2013). However, the results of other studies conducted by (Sunarwan, 2015) and (Rimardhani et al., 2016) indicate that the board of directors variable has no relationship or no effect on ROA. The board of directors variable has a positive value on ROE. (Wicaksono and Raharja, 2014) and (Septiana et al., 2016) show that the board of directors variable has a relationship with ROE. But this research contradicts the research conducted by (Istighfarin and Wirawati, 2015) stating that the board of directors has no effect on ROE.

The Board of Commissioners variable has no influence on profitability between the two independent variables which are proxied by Return on Assets (ROA) and Return on Equity (ROE). However, it has a negative relationship of $-0.28(-28 \%)$ towards ROA and RIE. This shows that the Board of Commissioners can reduce indirectly the performance of profitability which is proxied by Return on Assets (ROA) and Return on Equity (ROE). The results of this study are different from previous studies. (Fidanoski et al., 2014) showed a positive relationship between board of commissioners and ROA. (Sunarwan, 2015) and (Hutapea and Prasetiono, 2013) found an influential relationship between board of commissioners and ROA. This is because the more the board of commissioners, the oversight of the board of directors and managerial will be more stringent so that performance in the management of the company will also increase. The greater the ROA, the more efficient use of company assets will be. (Nwonyuku, 2016) shows that the board of commissioners has a positive relationship to ROE. The results of the study that are different from (Chukwudike, 2012) state that the board of commissioners has a negative relationship or no effect on ROE. The point of difference in the results of this study is that the Board of Commissioners has no influence and negative relationship to profitability which is proxied by ROA and ROE. Therefore, the number of the Board of Commissioners cannot guarantee an increase in profitability, but how effective the functions of the Board of Commissioners (DK) are in carrying out the functions of good governance so that all business targets of the company, especially Real Estate and Property, can achieve this with direction from the Board of Commissioners. 
Audit Committee variables have a significant influence on profitability. This is due to the prob value of the T-Statistic $0.0000<0.05$ so that the research hypothesis shows there is an influence between the independent variable Audit Committee (KA) on proxied profitability with Return on Assets (ROA) and Return on Equity (ROE). The Audit Committee has a positive relationship of $1.52(152 \%)$ to profitability which is proxied by Return on Assets (ROA) and Return on Equity (ROE). The results of this study are different from (Sunarwan, 2015), (Rimardhani et al., 2016), (Putra and Nuzula, 2017) showing that the audit committee has no effect on ROA. This is because the number of audit committees is only small, so that they cannot carry out their functions properly. The results of other studies by (Putra and Nuzula, 2017) show that the results that the audit committee has no influence on ROE. However, the research conducted by (Chukwudike, 2012) shows that the audit committee has a significant positive relationship to ROE. Therefore, the results of this study indicate that the effectiveness of the number of the Audit Committee is able to increase the amount of profitability of real-estate and property sector companies in Indonesia. The number of audit committees in the company will not affect the profitability and effectiveness in carrying out good corporate governance capable of improving the overall performance of the company both in terms of assets and equity.

\section{CONCLUSION}

Based on the explanation of the results of the research and discussion. Then the conclusions obtained from this study are that simultaneously the Board of Commissioners, the Board of Directors, and the Audit Committee have an effect on Return On Assets (ROA) and Return On Equity (ROE). Partially the Board of Directors and Audit Committee variables have a positive and significant influence on Return On Assets (ROA) and Return on Equity (ROE). The Board of Commissioners variable has no influence on Return On Assets (ROA) and Return on Equity (ROE). This study uses a panel data regression method with a common effect approach.

This research shows that the company's profitability performance is determined by the right corporate governance. Return on Assets (ROA) and Return on Equity (ROE) are indicators of how Good Corporate Governance (GCG) that is proxied with the Board of Commissioners, Board of Directors, and Audit Committee must work together in managing the company's business. The best implications for the company's business performance have a positive contribution to long-term sustainability. Several studies show that the three elements of Good Corporate Governance (GCG) play an important role in formulating, planning, and executing all the company's business strategies for the longterm future of the organization. Therefore, corporate governance must be implemented according to joint commitments so that the sustainability of the company can be maintained in the long term.

Based on the results of the research that has been done, it is expected that the next researcher will use variables whose data is always available every year so that researchers can facilitate the research sample. In addition, it is also recommended to increase the number of research periods so that the results obtained are more relevant. Subsequent research can be directed towards how Good Corporate Governance (GCG) can influence other business fields such as Employee Performance, Business Productivity, and Increased 
Sales. For investors, it is recommended that before investing their funds in the company to pay attention to the company's performance, one of them is by looking at the company's organizational structure, namely the board of commissioners, the board of directors and the company's share ownership. This is so that investors can see the extent to which the effectiveness of supervision has been carried out by the commissioners, the board of directors, and shareholders in monitoring the performance of the company.

\section{REFERENCES}

A Helfert, Erich. (2000). Technique and Financial Analysis, Tenth Edition, Mc Graw. Hill, New York.

Ajija, Shochrul R. Sari, Dyah W, Setianto, Rahmat H, Primanti, Martha R. (2011), Cara Cerdas Menguasai Eviews. Salemba Empat, Jakarta.

Anjani, L.P Ari. (2017). Pengaruh Good Corporate Governance Terhadap Profitabilitas pada Perusahaan Perbankan yang Terdaftar di BEI. Skripsi. Universitas Udayana.

Aldridge, John E, Siswanto Sutojo. (2008). Good Corporate Governance. Jakarta: PT. Damar Mulia Pustaka.

Bapepam. (2000). Surat Edaran Bapepam No.SE-03/PM/2000 Tentang Komite Audit.

Chukwudike, I.B. (2012). Impact of Corporate Governance on Organizational Profitability (A Study of Selected Listed Firms on The Nigerian Stock Exchange). Michael Okpara University of Agriculture, Umudike.

David, T. (2011). Pengaruh Good Corporate Governance (GCG) Terhadap Profitabilitas \& Kinerja Saham Perusahaan Perbankan Yang Tercatat DI Bursa Efek Indonesia. Journal of Business and Banking, 1(3), 1-14.

Eugene F. Brigham and Joel F. Houston. (2015). Fundamentals of Financial Management. Cengage Learning. https://doi.org/10.1016/0377-841X(78)90069-4.

Fidanoski, F, Vesna M dan Kiril S. (2014). Corporate Governance and Bank Performance: Evidence From Macedonia. Journal Economic Analysis, 47 (1-2), 76-99. University Library of Munich, Germany.

Filip, F., and Macedonia, R. (2014). Corporate governance and Bank Performance: Evidence from Macedonia. Economic Analysis, 47(1-2), 76-99. https://doi.org/10.5897/JAERD12.088.

FCGI. (2001). Seri Tata kelola Perusahaan (Corporate Governance). Edisi ke-2. Jakarta.

Ghozali, Imam. (2016). Aplikasi Analisis Multivariate dengan Program SPSS. Edisi ke 8. Semarang: Universitas Diponegoro.

Hardikasari, E., Hardikasari, E., and Pamudji, S. (2011). Pengaruh Penerapan Corporate Governance Terhadap Kinerja Keuangan Pada Industri Perbankan Yang Terdaftar Di Bursa Efek Indonesia (BEI) Tahun 2006-2008 (Doctoral dissertation, Universitas Diponegoro).

Heriyanto, S., and Mas'ud, I. (2016). Pengaruh Good Corporate Governance Terhadap Profitabilitas Perusahaan (Studi pada Perusahaan Manufaktur yang Terdaftar di Bursa Efek Indonesia Tahun 2012-2014). Artikel Ilmiah Mahasiswa.

Hutapea, A. J., and Prasetiono, P. (2013). Analisis Pengaruh Corporate Governance Terhadap Kinerja Keuangan Sektor Perbankan (Studi Pada Perusahaan Perbankan yang Terdaftar di BEI tahun 2007-2011) (Doctoral dissertation, Fakultas Ekonomika dan Bisnis). 
Islami, N. W. (2018). Pengaruh Corporate Governance terhadap Profitabilitas Perusahaan. Jurnal Ilmiah Bisnis dan Ekonomi Asia, 12(1), 54-58.

Istighfarin, D., and Wirawati, N. G. P. (2015). Pengaruh Good Corporate Governance Terhadap Profitabilitas Pada Badan Usaha Milik Negara (BUMN). E-Jurnal Akuntansi, 13 (2), 564-581, Universitas Udayana.

Jensen, Michael C, Meckling, William H. (1976). Theory of The Firm: Managerial Behavior, Ageng Cost and Ownership Structure. Jounal of Financial Economics, 3 (4).

Kajananthan, R. (2012). Effect of Corporate Governance on Capital Structure : Case of the Srilankan Listed. Gender in Management: An International Journal, 25(1), 5-21.

Komite Nasional Kebijakan Governance (KNKG). (2006). Pedoman Umum Good Corporate Governance. Jakarta. www.ecgi.com.

Marsella, L. (2013). Penerapan Good Corporate Governance pada Perusahaan Keluarga PT. Dai Knife. Agora, 1(3), 1476-1483.

Munawir. (2014). Analisis Laporan Keuangan. Yogyakarta: Liberty.

Noorizkie, Giska. (2013). Pengaruh Mekanisme Corporate Governance Terhadap Kinerja Keuangan Perusahaan (Studi Empiris pada Perusahaan Manufaktur yang Terdaftar di Bursa Efek Indonesia). Skripsi. Universitas Diponegoro.

Nurcahyani, Suhadak, dan R. Rustam Hidayat. (2011). Pengaruh Penerapan Good Corporate Governance dan Kepemilikan Institusional Terhadap Kinerja Keuangan (Studi pada Perusahaan Peserta CGPI yang Terdaftar di BEI tahun 2009-2011). Jurnal Administrasi Bisnis Fakultas Ilmu Administrasi. Universitas Brawijaya Malang.

Nwonyuku, K. (2016). Evaluating the Influence of Corporate Governance on Firm Profitability: The Case of Quoted Food and Beverages Companies in Nigeria. SSRN. https://doi.org/10.2139/ssrn.2891250.

Rimardhani, Helfiana, R. Rustam Hidayat, Dwiatmanto. (2016). Pengaruh Mekanisme Good Corporate Governance Terhadap Profitabilitas Perusahaan (Studi pada perusahaan BUMN yang Terdaftar di Bursa Efek Indonesia tahun 2012-2014. Jurnal Administrasi Bisnis (JAB), 31 (1).

Putra, A. S., and Nuzula, N. F. (2017). Pengaruh Corporate Governance Terhadap Manajemen Laba Pada Perusahaan Perbankan Yang Terdaftar Di Bursa Efek Indonesia. Jurnal Administrasi Bisnis, 47(Juni), 103-112. Retrieved from administrasibisnis.studentjournal.ub.ac.id

Rumapea, M. (2017). Pengaruh Good Corporate Governance Terhadap Profitabilitas Perusahaan Manufaktur Yang Terdaftar Di Bursa Efek Indonesia Periode 20132015. Methosika: Jurnal Akuntansi dan Keuangan Methodist, 1(1), 46-57.

Sanda, A. U., Mikailu, A. S., and Garba, T. (2010). Corporate governance mechanisms and firms' financial performance in Nigeria. Afro-Asian $J$. of Finance and Accounting, 2(1), 22. https://doi.org/10.1504/AAJFA.2010.035193.

Santoso, B. (2009). Sukses Berinvestasi Tanah, Rumah, Dan Property Komersial. Jakarta: PT. Elex Media Komputindo.

Sartono, Agus. (2010). Manajemen Keuangan: Teori dan Aplikasi. Edisi Keempat. Yogyakarta: BPFE.

Sawir, Agnes. (2005). Analisis Kinerja Keuangan dan Perencanaan Keuangan Perusahaan. Jakarta: Gramedia Pustaka. 
Septiana, N., Hidayat, R. R., and Sulasmiyati, S. (2016). Pengaruh Mekanisme Good Corporate Governance Terhadap Profitabilitas Perusahaan (Studi Pada Perusahaan Makanan Dan Minuman Tahun 2011-2014). Jurnal Administrasi Bisnis, 38(2), 147155.

Sukandar, P. P., dan Rahardja, R. (2014). Pengaruh Ukuran Dewan Direksi Dan Dewan Komisaris Serta Ukuran Perusahaan Terhadap Kinerja Keuangan Perusahaan (Studi Empiris Pada Perusahaan Manufaktur Sektor Consumer Good yang Terdaftar di BEI Tahun 2010-2012) (Doctoral dissertation, Fakultas Ekonomika dan Bisnis).

Sunarwan, Eko. (2015). Pengaruh Good Corporate Governance Terhadap Kinerja Keuangan Perbankan Syariah. Skripsi. UIN Syarif Hidayatullah Jakarta.

Surya, I., dan Yustiavandana, I. (2006). Penerapan Good Corporate Governance. Lembaga Kajian Pasar Modal dan Keuangan Fakultas Hukum Universitas Indonesia, Jakarta.

Tjondro, D., dan Wilopo, R. (2011). Pengaruh Good Corporate Governance (GCG) Terhadap Profitabilitas dan Kinerja Saham Perusahaan Perbankan Yang Tercatat di Bursa Efek Indonesia. Journal of business \& banking, 1(1), 1-14.

Tumewu, R. C., dan Alexander, S. (2014). Pengaruh Penerapan Good Corporate Governance terhadap Profitabilitas pada Perusahaan Perbankan yang terdaftar di BEI Periode 2009-2013. Accountability, 3(1), 77-85.

Undang-Undang No.40 Tahun 2007 tentang Perseroan Terbatas. Diakses 12 April 2018.

Wicaksono, T., dan Raharja, R. (2014). Pengaruh Good Corporate Governance Terhadap Profitabilitas Perusahaan (Studi Empiris pada Perusahaan Peserta Corporate Governance Perception Index (CGPI) Tahun 2012) (Doctoral dissertation, Fakultas Ekonomika dan Bisnis).

Veno, Andri. (2015). Pengaruh Good Corporate Governance Terhadap Kinerja Perusahaan pada Perusahaan Manufaktur Go Public (Studi Empiris pada Perusahaan yang Terdaftar di BEI tahun 2011-2013). Jurnal Manajemen dan Bisnis, 19 (1), 95-112, Universitas Muhammadiyah Surakarta.

Yuniarti, C. (2014). Pengaruh Good Corporate Governance terhadap kinerja dan nilai perusahaan pada perusahaan High Profile yang terdaftar di BEI tahun 2011-2013. Jurnal Program Studi Akuntansi Fakultas Ekonomi UNY. 